\title{
The Changing Federal Role in Support of Public Transportation
}

\author{
Jack R. Gilstrap \\ Executive Vice President, American Public Transit Association
}

Public transportation is working for America every day, carrying people to jobs, the elderly to health services, and students to school. It is an essential element of America's transportation infrastructure, and part of the economic engine that keeps our nation running. From crowded cities to rural America, people depend on public transportation nine billion times each year to keep their lives in motion, at an affordable price.

As a 30-year partner with the federal government-across eight Republican and Democratic administrations-public transportation is good value for the money. It fuels our nation's economy by promoting jobs and leading to personal economic independence. It serves people with disabilities. As an essential element of interstate commerce, it frees up commuter highways so goods and services can get to market efficiently. And it stimulates private development while enhancing our quality of life.

A strong federal transit program has an important role in any vision of America's future. In an era of limited resources, federal policy must encourage efficient use of all transportation resources. Only transit simultaneously reduces congestion, limits pollution, provides accessible transportation for all Americans, and saves energy. 
Over the past 30 years, the U.S. transit industry and its riders have prevented:

- the emission of 1.6 million tons of hydrocarbons, 10 million tons of carbon monoxide, and 275,000 tons of nitrogen oxides into our air;

- the importation of 20 billion gallons of gasoline; and

- the construction and maintenance of 20,000 lane-miles of freeways and arterial roads and 5 million parking spaces to meet rush-hour demands, saving at least $\$ 220$ billion (as much as all federal highway spending for the last 15 years).

We provide these benefits by serving people who would otherwise have driven their own vehicles, adding to congestion, pollution, and increasing the demand for public spending on roads. Federal policy should increase, not reduce, the incentive for people to choose transit so these benefits can be maintained. The federal role takes on renewed importance, given the findings in numerous recent studies that subsidies for automobiles and trucks are somewhere between $\$ 378$ billion and $\$ 935$ billion per year.

We also have served people who depend on transit as a primary source of mobility. Some are too poor to own and operate personal vehicles. Some are unable to drive because of age, youth, or other reasons. Transit provides essential mobility to some 80 million Americans without ready access to personal vehicles.

Following are five reasons why the federal transit program should be preserved.

- Access to Economic Opportunity. For millions of American workers, transit means access to job opportunities and economic independence. Public transit serves low-income workers and minorities in disproportionate numbers. Approximately one out of four transit riders is from a family with below-poverty-line income. This is almost double the 14.2 percent of Americans below the Census Bureau's poverty level of $\$ 13,924$ for a family of four.

Transit fares rose 22 percent above inflation from 1980 to 1993. Cuts in federal operating aid will mean fare increases and service reductions, making it 
harder for transit-dependent workers to commute. Now is not the time to limit access to personal economic independence through work.

Affordable transit has important implications for the success of welfare reform. All welfare reform proposals seek to move people from the welfare rolls into jobs. The existing Job Opportunities and Basic Skills (JOBS) training program recognizes that people need transportation to move from welfare to work. JOBS-related transportation benefits include the provision of tokens or tickets (32 states), reimbursement for public transportation (21 states), and rideshare/ vanpool/carpool benefits (21 states). For example, Arizona allows $\$ 6$ per day for reimbursement of transit costs, and Georgia allows $\$ 35$ per month for tokens or tickets. Since 1989, JOB-RIDE (a Wisconsin Department of Transportation reverse commute program) has provided access to more than 3,500 suburban jobs, reducing the Aid to Families with Dependent Children/general assistance/ unemployment rolls.

Current state welfare reform efforts also recognize the importance of transportation. The recently-passed Virginians' Initiative for Employment not Welfare (VIEW) is one example. Local social service agencies are authorized to give VIEW families "assistance with transportation, if such transportation enables the individual to work."

- An Alternative to Congestion. In 1992, congestion cost individual drivers more than $\$ 45$ billion in wasted time and fuel in 50 U.S. metropolitan areas. Interstate commerce is threatened as businesses pay billions of dollars in reduced productivity and higher shipping costs. Every year, the economic losses from congestion are growing in suburbs and central cities. America's metropolitan areas are investing in transit to protect themselves from future traffic gridlock and economic stagnation. Congress should encourage local efforts to safeguard our economic future by maintaining transit funding and protecting ISTEA's flexible funding programs and provisions to guarantee equitable consideration of transit investments.

- More Transportation Choices. Over the past several years, transit ridership has increased. Especially noteworthy are the significant commuter rail rid- 
ership increases because they demonstrate that there is a demand for transit options in suburban communities. Whether or not they ride transit, all Americans benefit when affordable transit gives people more transportation choices. Cuts in federal transit funding will mean higher fares and service reductions. Some riders will return to their personal vehicles, making it harder to reduce congestion, clean up the air, and conserve energy. Transit-dependent people will have no choice but to limit their travel.

It is no accident that Governor Christine Todd Whitman of New Jersey has proposed to freeze her state's transit fares. Governor Whitman understands that improving the quality of life for her constituents depends on infrastructure investments, preservation of a wide range of transportation choices, and support for transit's ability to reduce congestion, clean up the air, and improve mobility for everyone in the community.

- The Cost of Federal Mandates. The issue of federal mandates is very important to the transit industry. APTA recommends that no additional unfunded federal mandates be imposed on providers of public transportation services. We welcomed the enactment of the Unfunded Mandates Reform Act of 1995 because it brought a healthy perspective to future discussions of mandates. The new law did not, however, limit the federal mandates that add more than $\$ 790$ million in operating and $\$ 340$ million in capital expenses each year to state and local transit agency budgets.

We support the goals of the Americans with Disabilities Act (ADA), the Clean Air Act, federal drug and alcohol testing laws, the Clean Water Act, and other laws that impose mandates on transit systems. But these goals cannot be achieved without sufficient funding. Without federal aid to compensate for these costs, transit agencies are forced to raise fares or reduce services. Higher fares and service cuts hurt those who depend on transit and make it harder to attract customers away from their personal vehicles, jeopardizing progress in reducing congestion, cleaning up polluted air, conserving energy, and making the most efficient and productive use of our transportation resources.

While APTA has developed a capital incentive policy in response to outlay constraints, it is still true that mandates cost our transit systems much more than 
the current $\$ 400$ million in operating aid. The estimated annual operating costs of three federal mandates are: ADA, $\$ 693$ million; federal drug and alcohol testing requirements, $\$ 44$ million; and Clean Air Act fuel costs, $\$ 57$ million.

The Americans with Disabilities Act establishes a civil right to transit service for people with disabilities. The transit industry wants to comply with ADA and meet the needs of other riders-a major challenge, without full funding of ADA capital and operating costs that exceed $\$ 950$ million per year. ADA is a promise that should be kept so people with disabilities can participate fully in our society. Our entire society must share in the costs of keeping this promise; transit operators cannot do it alone.

- The Public-Private Transit Partnership. The transit industry historically has been a working partnership between public agencies and private businesses. Transit's greatest economic contribution is to move people efficiently, providing access to jobs and reducing the economic costs imposed by congestion. The federal transit program provides critical support for local efforts to improve private sector productivity by providing more transportation choices. In northern Virginia, for example, development around Metrorail stations has generated 65,000 permanent jobs since 1973 and provided a net gain of $\$ 1.2$ billion in tax revenues. Modernization of existing transit systems also promises significant economic benefits. A 1991 study found that full investment in Philadelphia's transit agency would return $\$ 9$ to the economy for each $\$ 1$ invested. As firms located near the new St. Louis Metrolink rail system and many other transit lines have found, proximity to transit is good for business.

Transit operators are applying business principles to improve productivity. Between 1988 and 1993, the real cost of transit service went down by 6.5 percent per vehicle mile despite greater federal regulations and mandates. Average transit wages are lower than wages for workers in motor vehicle manufacturing, water transportation, highway construction, and other transportation and public utility jobs. In fact, many transit agencies purchase service from privately-owned firms. Commuter rail, fixed-route bus, and demand-responsive paratransit services are some of the services that private firms supply. 
APTA wants to continue to work with Congress to encourage innovative public-private investments without limiting local flexibility. We will continue to develop new policy initiatives, including proposals to encourage more private investment in transit capital projects and encouragement of the public-private transit partnership.

\section{Maintaining the Federal Investment in Transit}

APTA wishes to strengthen partnerships among all levels of government and the private sector, recognizing that state and local governments are best able to set priorities that respond to local needs and conditions. APTA encourages and wants to accelerate the ongoing efforts of Congress, the Federal Transit Administration, and other governmental agencies to eliminate unnecessary federal regulations and improve the efficiency of federal programs. This includes modifying ISTEA's planning requirements so that limited transportation funds can be spent in the most cost-effective ways.

The federal transit program is critical to the nation's well-being. Federal investment in transit infrastructure produces valuable assets in every community and long-term benefits for the nation. For example, there is a definite connection between effective transit service and operating efficiency of our National Highway System. The more people use transit, the less crowded urban roadways are. Fewer cars on the road means that commercial vehicles will move more efficiently, without the need for additional highway construction that has become prohibitively expensive in many regions.

Furthermore, transit also provides mobility and economic independence to millions of people each day. About 55 percent of the nine billion annual transit trips are taken to and from the work place, and each $\$ 10$ million invested in transit creates or maintains 550 full time jobs in a community.

Transit is also vital to the success of welfare reform. Many current welfare recipients do not own cars and must rely on public transportation to get to work. Increasingly, new jobs are being created in the suburbs, and transit operators are providing central-city dwellers with access to the job markets with special bus, rail, and van services. 
Transit is also critical to economic development. It returns three times its cost in business revenue to the communities it serves, according to an APTA study. When cities add a bus route or build a rail station, they stimulate private investment around the new transit service in the form of housing, retail, and other privately-financed development.

Our industry is working vigorously to deal with the new reality of federal funding. Last year's cut of nearly 12 percent in overall transit funding and almost 50 percent in operating assistance has forced transit systems to raise fares and cut service. We are working at the state and local levels to enhance public and private financing and revenue. These state and local efforts can work best if the federal program provides a stable source of funding in FY 1997 and beyond.

\section{Capital Funding Needs}

The transit industry's capital funding requirements are $\$ 13.9$ billion per year from 1995 through 2004. Over this ten-year period, capital needs include:

- $\$ 35$ billion for new vehicles, including 67,800 buses and 51,400 vans;

- $\$ 23$ billion for new bus facilities including parking facilities for bus passengers;

- $\$ 22$ billion to modernize and rehabilitate existing fixed guideway rail and bus routes, stations, and maintenance facilities;

- $\$ 43$ billion for additional fixed guideway services that respond to new customer demands; and

- $\$ 4$ billion to rehabilitate more than 14,900 buses, rail cars, and other vehicles to extend their useful lives.

The typical transit agency depends on federal funds for 63 percent of its budget to buy new vehicles and upgrade old facilities. A decrease in federal support for capital investments will cause immediate hardships for transit customers. In the long run, communities of all sizes will pay a price, both in decreased mobility for individuals and in reduced productivity as congestion forces up the costs of moving goods in interstate and local commerce. 


\section{APTA Reauthorization Proposals}

The Intermodal Surface Transportation Efficiency Act (ISTEA) reformed Federal policy to meet the mobility challenge of the post-Interstate era by integrating surface transportation planning, programs, and services. ISTEA recognizes that our economic health and the quality of life in our communities depend on more efficient use of infrastructure and careful planning in regions and states.

ISTEA also addresses the complications posed by the environmental and social impacts of massive urban freeway construction, which has helped to build up public resistance to needed transportation improvements. We need more effective strategies to blend transportation infrastructure into the social and neighborhood fabric of our cities and suburbs, addressing human needs and impacts as well as physical engineering questions.

The Federal government looks to public transit to provide transportation for people with disabilities, the elderly, and other transit-dependent riders; to protect the environment and conserve energy; and to ease the burden on crowded roads.

By standing firm on ISTEA's reforms and allowing the federal-state-local transportation partnership to flourish, the Federal government can ensure that transit will function even more effectively as a thriving part of a balanced national transportation system. Continued federal support for balanced transportation will enable every community to improve its transit service and increase the range of affordable, convenient transportation options, revitalize our central cities, maintain the health of our suburbs, and weave our smaller towns and rural America more closely into the fabric of our national life.

The mission of public transportation is to foster personal mobility, economic opportunity, and an improved quality of life through partnerships, communication, and technology. Investments in transit are needed to enhance the economic health and the quality of life in central cities, suburbs, small towns, and rural areas. These transit investments will improve the quality of all citizens' lives.

Accordingly, APTA makes the following recommendations for the reauthorization of ISTEA:

1. ISTEA's innovative flexible funding and level playing field provisions have been successful and should be retained. Among these are the Surface Trans- 
portation Program; the Congestion Mitigation and Air Quality (CMAQ) program, with metropolitan suballocations; the equal 80 percent federal shares for highway and transit projects; and the use of local "soft match" for transit projects. Additional flexible funding should be authorized by expanding the Surface Transportation Program using revenue from the Highway Trust Fund's Highway Account and Mass Transit Account.

2. The existing transit program structure should be retained because it works well. Fiscal Year 1998 funding for the transit program should be authorized at the Fiscal Year 1996 authorized level of $\$ 5.125$ billion and should be adjusted for inflation in later years.

3. Expand the definition of allowable capital expenditures to include maintenance and mandate relief.

Despite ISTEA's overall record of success, annual appropriations measures have significantly reduced urbanized area transit operating assistance, causing serious problems for transit agencies. To ameliorate the problems caused by this operating assistance shortfall, APTA proposes to expand the transit program's definition of allowable capital expenditures. For small UZAs, APTA proposes to eliminate the distinction between capital and operating assistance as is now the case for non-urban areas, so that transit operators in these areas could use all of their funds for capital or operating purposes as currently defined. If Congress retains operating assistance for large UZAs, APTA further proposes that transit operators in these UZAs be able to trade in $\$ 1$ of operating assistance for $\$ 2$ of capital assistance.

4. Support transit in small urbanized areas and rural areas by keeping the existing ISTEA formulas for smaller UZA and non-urban funding. Also, a provision should allow these funds to be used for operating assistance. Minimum regulatory requirements should be imposed for these areas.

5. To create more stability and predictability in annual transit funding levels, APTA proposes that transit funds be appropriated in a block amount as is done for the Federal-Aid Highway Program. This would result in a uniform firstyear outlay rate for the total transit program in the same way that a uniform firstyear outlay rate is calculated for the Federal-Aid Highway Program. Enactment 
of this proposal would establish equality in first-year outlay rates for transit and highways and establish a level playing field for the highway and transit programs in the way they are treated in the budget and appropriations processes.

6. Increase the Federal Transit Program's efficiency by building on Congressional and U.S. Department of Transportation initiatives in the area of administrative and regulatory changes in a number of areas. These changes should include, among others:

- increasing capital flexibility by eliminating the associated capital maintenance item threshold and expanding capital maintenance eligibility to be consistent with FHWA programs;

- applying Federal procurement requirements only to capital funds;

- permitting transit operators to coordinate or combine Federal and state reviews to avoid duplication of efforts;

- modifying the employee benefit for parking to narrow the difference between the $\$ 65$ per month tax-free transit benefit and the $\$ 165$ per month tax-free parking benefit; creating a federal income tax deduction for transit commuter expenses;

- ensuring that compliance with the Americans with Disabilities Act establishes a method that accommodates financial burden on transit systems, provides discretion to local officials, defines compliance that is certified by the FTA, and strengthens the coordination process at the federal level to ensure transit access to all Federal funding for transportation services; and

- reforming section 13 (c) legislatively with respect to its applicability, to ensure that it complies with the Administrative Procedure Act (APA) and is subject to a time limit.

7. Modify the Congestion Mitigation and Air Quality program. Steady annual increases in flexible funding transfers to transit demonstrate that ISTEA's flexible funding provisions respond to the needs of states and metropolitan regions. APTA favors adjustments to the CMAQ program so it will continue to provide resources for areas that come into attainment, but that continue to face 
serious congestion problems and potential deterioration of air quality in the long term. The Federal government should not penalize states and regions for achieving air quality goals.

8. ISTEA's planning provisions are fundamentally sound, including current authority for Metropolitan Planning Organizations, public participation requirements, transportation and land use linkages, and multimodal corridor analysis through the Major Investment Study (MIS) criteria. APTA recommends changes to ensure that the planning process fully accounts for often-ignored benefits of transit investments and to provide sufficient resources so that planning does not become another "unfunded federal mandate."

9. Apply the highway solvency test instead of the more stringent mass transit solvency test to the Mass Transit Account. Spending from the Mass Transit Account of the Highway Trust Fund should be required to comply with the Byrd Test instead of the more restrictive Rostenkowski Test. This change will create a more level playing field between highways and transit since the Byrd Test applies to the Highway Account.

10. Return the 4.3 cents per gallon gasoline tax now used for general government spending to the Highway Trust Fund. In keeping with the precedent set by President Reagan, a minimum of 20 percent of this amount should be deposited into the Mass Transit Account.

11. Continue to support the Transit Cooperative Research Program (TCRP), University Transportation Centers, and university institutes created by ISTEA. Create a new Technology Development and Demonstration Program. TCRP makes a significant contribution to the national interest, and it deserves continued support. Likewise, the university transportation centers (UTCs) and the university institutes established by ISTEA also conduct important research, education, and training programs. The next authorization should retain these programs and provide them with no less than their current percentage of transit program funding. APTA also recommends the creation of a Technology Development and Demonstration Program as a partnership of the Federal government, transit agencies, and the private sector to support the implementation of new transit technologies and practices. 
12. Allow states to use the state shares of flexible funding programs for intercity passenger rail and commuter rail investments, provided there is an increase in the total amount of flexible funding available (as proposed in recommendation \#1).

\section{Conclusion}

In 1991, ISTEA gave states and metropolitan areas more control over transportation decisions, reduced federal biases against local transit investments, and called for more efficient ways to increase personal mobility. The next Congress should support ISTEA's pioneering efforts to strengthen the economy and return power to states and local communities.

Federal transit investments give people more transportation choices, improve economic productivity, and protect the quality of life in our communities. As rising congestion points toward economic stagnation and decreasing mobility for all Americans, the national interest depends on a strong federal transit program.

\section{About the Author}

JACK R. GiLSTRAP is Executive Vice President of the American Public Transit Association. He is retiring in early October after leading the association for 16 years. 